The Company and the Shogun 
COLUMBIA STUDIES IN INTERNATIONAL AND GLOBAL HISTORY Matthew Connelly and Adam McKeown, Series Editors

The idea of "globalization" has become a commonplace, but we lack good histories that can explain the transnational and global processes that have shaped the contemporary world. Columbia Studies in International and Global History will encourage serious scholarship on international and global history with an eye to explaining the origins of the contemporary era. Grounded in empirical research, the titles in the series will also transcend the usual area boundaries and will address questions of how history can help us understand contemporary problems, including poverty, inequality, power, political violence, and accountability beyond the nation-state.

Cemil Aydin, The Politics of Anti-Westernism in Asia: Visions of World Order in Pan-Islamic and Pan-Asian Thought

Adam M. McKeown, Melancholy Order: Asian Migration and the Globalization of Borders

Patrick Manning, The African Diaspora: A History Through Culture

James Rodger Fleming, Fixing the Sky: The Checkered History of Weather and Climate Control

Steven Bryan, The Gold Standard at the Turn of the Twentieth Century: Rising Powers, Global Money, and the Age of Empire

Heonik Kwon, The Other Cold War

Samuel Moyn and Andrew Sartori, eds., Global Intellectual History 


\title{
The Company and the Shoqun
}

THE DUTCH ENCOUNTER WITH

TOKUGAWA JAPAN

\section{Adam Clulow}

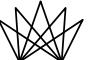 \\ Columbia University Press \\ New York
}




\section{Columbia University Press}

Publishers Since 1893

New York Chichester, West Sussex

cup.columbia.edu

Copyright (C) 2014 Columbia University Press

All rights reserved

Library of Congress Cataloging-in-Publication Data

Clulow, Adam.

The company and the shogun: The Dutch encounter with

Tokugawa Japan / Adam Clulow.

pages $\mathrm{cm}$. - (Columbia studies in international and global history)

Includes bibliographical references and index.

ISBN 978-o-231-16428-3 (cloth: alk. paper)

-ISBN 978-o-231-53573-1 (e-book)

1. Nederlandsche Oost-Indische Compagnie-History. 2. Japan-CommerceNetherlands-History. 3. Netherlands-Commerce-Japan-History.

4. Japan-History-Tokugawa period, 160o-1868. I. Title.

$\begin{array}{cr}\mathrm{HF}_{483} \cdot \mathrm{E}_{6} \mathrm{C}_{5} 8 & 2014 \\ 382.09492^{\prime} 052-\mathrm{dc23} & 2013019450\end{array}$

Columbia University Press books are printed on permanent and durable acid-free paper.

This book is printed on paper with recycled content.

Printed in the United States of America

C 10987654321

Jacket design by Julia Kishnirsky

Jacket artwork: Merchant Ship of the Dutch East India Company, 1782.

Nagasaki School, published by Toshimaya Hand coloured woodblock print. $65 \times 58 \mathrm{~cm}$. Courtesy of Bonhams Picture Library

References to websites (URLs) were accurate at the time of writing. Neither the author nor Columbia University Press is responsible for URLs that may have expired or changed since the manuscript was prepared. 